\title{
The role of Kisspeptin in bovine in vitro embryo production
}

\section{Efeito da Kisspeptina na produção in vitro de embriões bovinos}

\author{
Mayara Mafra Soares ${ }^{1}$; Deize de Cássia Antonino ${ }^{1}$; Mayara Oliveira ${ }^{1}$; Jairo Melo \\ Júnior $^{1}$; Luciana Ribeiro Peixoto우 Tatiane Silva Maia'; Kele Amaral Alves²; José \\ Octávio Jacomini ${ }^{3}$; Ricarda Maria dos Santos ${ }^{3}$; Gustavo Guerino Macedo ${ }^{3 *}$
}

\begin{abstract}
The aim of this study was to investigate the effect of Kisspeptin (Kp) on the medium used in different stages of in vitro production of bovine embryo (IVEP), evaluating cleavage (CR) and blastocyst (BR) rates. The study was divided into three experiments that analyzed, respectively, the action of Kp on in vitro maturation (IVM), in vitro fertilization (IVF), and in vitro culture (IVC) of bovine embryos. In experiment 1, the oocytes were matured in IVM medium and distributed into the following treatments:

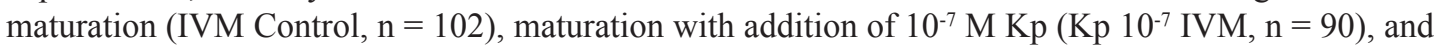
hormone-free maturation luteinizing hormone (LH) and follicle-stimulating hormone (FSH) with the

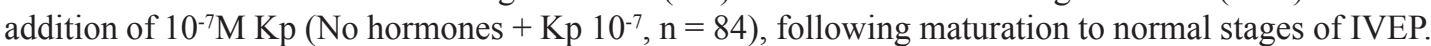
In experiment 2 , the oocytes were fertilized in IVF medium, in the following treatments: TALP-FERT without $\mathrm{Kp}$ (Control IVF, $\mathrm{n}=103)$ and TALP-FERT with the addition of $10^{-7} \mathrm{M} \mathrm{Kp}\left(\mathrm{Kp} 10^{-7} \mathrm{IVF}, \mathrm{n}=\right.$ 119), usually following the other steps. Finally, in the third experiment, the oocytes passed through all phases and were divided into IVC in two treatments: SOF medium without Kp (Control IVC, $\mathrm{n}=$ $109)$ and SOF medium with the addition of $10^{-7} \mathrm{M} \mathrm{Kp}\left(\mathrm{Kp} \mathrm{10}^{-7}, \mathrm{~N}=106\right)$. The data were analyzed by PROC GLIMMIX of the SAS program. In experiment 1 , the means of CR and BR were similar (P > 0.05 ) between treatments (IVM Control76.47\% and 37.25\%, Kp $10^{-7}$ MIV80\% and 33.33\%, and No hormones $+\mathrm{Kp} 10^{-7} 70.24 \%$ and $30.95 \%$, respectively). In experiment 2 , the means of CR were similar for the IVF Control and $\mathrm{Kp} 10^{-7}$ IVF groups ( $\left.\mathrm{P}>0.05\right), 76.70 \%$ and $86.55 \%$ respectively. But, the mean of the BR of the group Kp $10^{-7} \mathrm{IVF}$ was $38.66 \%$, which was higher $(\mathrm{P}<0.05)$ than that of the FIV Control group, which was $31.07 \%$. In the third experiment, the means of $\mathrm{CR}$ and $\mathrm{BR}(\mathrm{P}>0.05)$ were similar between the IVC Control and Kp $10^{-7}$ IVC groups (CR $83.50 \%$ and $78.30 \%$, and BR $26.60 \%$ and $23.60 \%$, respectively). Although at this concentration of $10^{-7} \mathrm{M}$ during IVC no change in embryo production is seen, $\mathrm{Kp}$ presents the same performance as both gonadotrophins in oocyte maturation and modulates the fertilization process, providing more blastocysts. With these findings, it can be seen that $\mathrm{Kp}$ presents a regulatory action on bovine reproduction, and can be an excellent tool to maximize IVEP indexes.
\end{abstract}

Key words: Blastocysts. In vitro culture. In vitro maturation. In vitro fertilization. Kiss1. Kiss1r.

\section{Resumo}

Objetivou-se com esse estudoinvestigar o efeito da Kisspeptina (Kp) nos meios base utilizados nas etapas da Produção in vitro de Embriões (PIVE) bovinos, avaliando as taxas de clivagem (TC) e blastocistos (TB). O estudo foi dividido em três experimentos, sendo respectivamente analisado em cada um a ação

\footnotetext{
${ }^{1}$ Discentes, Faculdade de Medicina Veterinária da Universidade Federal de Uberlândia, FAMEV/UFU, Uberlândia, MG, Brasil. E-mail: may_vetufu@yahoo.com.br; deize.bio@gmail.com; may.udi@gmail.com; jairo.vet@hotmail.com; lucianarpeixoto@ gmail.com; tatiane.silva.maia@hotail.com

2 Pesquisadora, FAMEV/UFU, Uberlândia, MG, Brasil. E-mail:ketevet@gmail.com

3 Profs., FAMEV/UFU, Uberlândia, MG, Brasil. E-mail:jojacomini@ufu.br; ricarda.santos@ufu.br; gmacedo@ufu.br

* Author for correpondence
} 
da Kp na maturação in vitro (MIV), fertilização in vitro (FIV) e cultivo in vitro (CIV) de embriões bovinos. No experimento 1 os oócitos foram maturados em meio base MIV, distribuídos nos seguintes tratamentos: maturação (Controle MIV, $\mathrm{n}=102)$, maturação com adição de $10^{-7} \mathrm{M}$ de $\mathrm{Kp}-10\left(\mathrm{Kp} \mathrm{10^{-7 }}\right.$ MIV, $n=90$ ) e maturação sem hormônios LH e FSH com adição de $10^{-7} \mathrm{M}$ de Kp-10 (Sem hormônios + $\mathrm{Kp} 10^{-7}, \mathrm{n}=84$ ), seguindo após a maturação para as etapas normais da PIVE. No experimento 2 os oócitos foram fecundados em meio base da FIV, nos seguintes tratamentos:TALP-FERT sem Kp (Controle FIV, $\mathrm{n}=103)$ e TALP-FERT com adição de $10^{-7} \mathrm{M}$ de Kp-10 $\left(\mathrm{Kp} \mathrm{10} 0^{-7} \mathrm{FIV}, \mathrm{n}=119\right)$, seguindo normalmente pelas outras etapas. Finalmente, no terceiro experimento os oócitos passaram por todas as fases e foram divididos no CIV em 2 tratamentos: meio SOF sem Kp (Controle CIV, $\mathrm{n}=109)$ e meio SOF com adição de $10^{-7} \mathrm{M}$ de $\mathrm{Kp}-10\left(\mathrm{Kp} \mathrm{10^{-7 }} 3, \mathrm{n}=106\right)$. Os dados foram analisados pelo PROC GLIMMIX do programa SAS. No experimento 1 as médias das TC e TB foram semelhantes $(\mathrm{P}>0,05)$ entre os tratamentos Controle MIV 76,47\% e 37,25\%, Kp $10^{-7}$ MIV 80\% e 33,33\% e Sem hormônios + Kp 10$770,24 \%$ e $30,95 \%$, respectivamente. No experimento 2 as médias das TC foram semelhantes para os grupos Controle FIV e Kp $10^{-7}$ FIV ( $\left.\mathrm{P}>0,05\right)$, sendo 76,70\% e 86,55\%, respectivamente. Porém, a média da TB do grupo Kp $10^{-7}$ FIV 38,66\%, foi superior $(\mathrm{P}<0,05)$ ao grupo controle FIV $31,07 \%$. No terceiro experimento as médias das TC e TB $(\mathrm{P}>0,05)$ também foram similares entre os tratamentos Controle CIV e Kp $10^{-7} \mathrm{CIV}$. Os seguintes valores foram observados para TC 83,50\% e 78,30\% e TB $26,60 \%$ e $23,60 \%$ respectivamente. Embora nesta concentração de $10^{-7} \mathrm{M}$ durante a CIV não seja visto alteração na produção de embriões, a Kp apresenta o mesmo desempenho que ambas as gonadotrofinas na maturação de oócitos e modula o processo de fertilização proporcionando mais blastocistos. Com isso, pode-se perceber que a Kisspeptina apresenta uma ação regulatória na reprodução de bovinos, podendo ser uma excelente ferramenta para maximizar os índices da PIVE.

Palavras-chave: Blastocistos. Cultivo in vitro. Fertilização in vitro. Maturação in vitro. Kiss1. Kiss1r.

\section{Introduction}

Biotechnologies of reproduction are being used as tools to maximize the reproductive efficiency of herds, primarily cattle, resulting in a higher number of offspring. In addition, the genetic merit of the herd is indirectly increased, since these techniques provide the massive dissemination of the superior material, thus increasing the genetic progress for time (LIMA; STERZA, 2016). An important biotechnology to exploit this genetic potential is the in vitro embryo production (IVP), which allows a reduction of the interval between generations, besides allowing the introduction/intensification of the genetic material of females identified as superior.

However, this biotechnology still performs less than ideal for embryo production, with a $40 \%$ rate of oocytes reaching the stage of blastocysts (LONERGAN; FAIR, 2008) for commercial laboratories and $30 \%$ in the research environment (MAPLETOFT, 2013). To this end, studies are being developed to find alternatives and products that can increase production rates in IVP and improve the quality of blastocysts.
In this context, the discovery of the Kisspeptin $(\mathrm{Kp})$ action as the main factor in fertility control, acting at different levels from hypothalamic nuclei (REDMOND et al., 2011) to gametes (HSU et al., 2014; PINTO et al., 2012; SAADELDIN et al., 2012), and opening a window for the understanding of how the modulation of oogenesis, fertilization, and embryonic/fetal development occurs. Metastin (commonly known as Kp), discovered by Lee et al. (1996), had its KISS1 gene first described as one of the metastatic suppressor genes in malignant melanoma cells. Kp is a product of the KISS1 gene with affinity for the KISS1 receptor (KISS1R), which is a transmembrane $G$ protein-coupled receptor, previously recognized as GPR54 (HIDEN et al., 2007; PINILLA et al., 2012).

This peptide acts primarily on the hypothalamus, stimulating gonadotropin-releasing hormone $(\mathrm{GnRH})$ neurons, resulting in pulsatile or tonic secretion and promoting the release of luteinizing hormone (LH) and follicle stimulating hormone (FSH) (EZZAT et al., 2010; GUTIÉRREZPASCUAL et al., 2007). The expression of the 
gene encoding this neuropeptide and its receptor has already been observed in reproductive tissues, including ovary (CASTELLANO et al., 2006; GAYTAN et al., 2009), oviduct (GAYTAN et al., 2009), and testes (OHTAKI et al., 2001; TERAO et al., 2004; ZHAO et al., 2010). Kp and its receptor were also detected in human spermatozoa (PINTO et al., 2012) and Kiss1r in mouse spermatozoa (HSU et al., 2014), suggesting a regulatory role in reproduction at these levels. Although $\mathrm{Kp}$ acts indirectly by stimulating folliculogenesis, spermatogenesis, and steroidogenesis, besides promoting ovulation in females (MACEDO et al., 2013, OKAMURA et al., 2013), there is still no study on the role of Kp in each step of IVP in cattle. Thus, the aim of this study was to investigate the effect of Kp supplementation on the base media used in the in vitro maturation, fertilization, and in vitro culture of bovine embryos, evaluating the production of embryos through the cleavage and blastocyst rates.

\section{Material and Methods}

\section{Reagents}

The reagents used in this study were from Sigma (St. Louis MO, USA). Murine Kp-10 (YNWNSFGLRY-NH2) was manufactured by American Peptide Company Inc., (Vista, CA, USA). Follicle-stimulating hormone (FSH; Folltropin ${ }^{\circledR}$ ) and luteinizing hormone (LH; Lutropin-V( $\left.{ }^{\circledR}\right)$ were sourced from Bioniche Inc. (Belleville, Canada).

\section{Local and Animals}

Ovaries were collected from a bovine slaughterhouse in the municipality of UberlândiaMG, varying the breed, age, and weight of the animals. The ovaries were transported in a thermal bottle with a temperature between $35^{\circ} \mathrm{C}$ and $38^{\circ}$ $\mathrm{C}$, in a maximum period of 4 hours. The collected material was taken to the Animal Reproduction Laboratory of the Federal University of Uberlândia.
Collection and selection of cumulus-oocyte complexes

Immediately after the ovaries arrived, the oocytes were obtained by suctioning the ovarian follicles with a diameter of 3 to $8 \mathrm{~mm}$, punctured with the aid of an 18-gauge needle attached to a $5 \mathrm{~mL}$ syringe. The obtained follicular fluid was deposited into $15-\mathrm{mL}$ plastic tubes and allowed to stand in a water bath $\left(35^{\circ} \mathrm{C}-38^{\circ} \mathrm{C}\right)$ for 10 minutes until sedimentation. The pellet formed was transferred to Petri dishes and evaluated under a stereoscopic microscope (Olympus Optical ${ }^{\circledR}$, model SZ-40/SZST) for the tracking of cumulus-oocyte complexes (COCs).

The classification of the oocytes was performed by a single observer, based on the Leibfried and First (1979) method with adaptations, in which the COCs were classified according to their morphology into the following: grade I (homogeneous nucleus and ooplasm with more than 3 layers of cumulus cells); grade II (compact COCs with three or fewer layers of cumulus and oocyte cells with slightly heterogeneous cytoplasm); and grade III (partially bare oocytes, showing removal of cumulus cells on less than a third of the surface of the zona pellucida, naked, and atresic). The COCs classified into grade I and grade II were used for IVM. The study was divided into three experiments, and each replicate of each experiment had the same quality and quantity of oocytes per treatment.

\section{In vitro embryo production}

\section{Experiment 1}

After the selection, the oocytes were transferred to the IVM stage, washed twice in TCM-199 Hepes base wash medium plus $10 \%$ fetal bovine serum, pyruvate solution $\left(0.11 \mathrm{mg} / \mathrm{mL}^{-1}\right)$, and amikacin $\left(83 \mathrm{mg} / \mathrm{mL}^{-1}\right)$. After this process, the oocytes were randomly divided into 3 treatments: conventional maturation (IVM Control, $\mathrm{n}=102$ ), maturation with the addition of $10^{-7} \mathrm{M} \mathrm{Kp}\left(\mathrm{Kp} 10^{-7} \mathrm{IVM}, \mathrm{n}=\right.$ 
90), and maturation without $\mathrm{LH}$ hormones and FSH with the addition of $10^{-7} \mathrm{M} \mathrm{Kp}$ (No hormones $\left.+\mathrm{Kp} 10^{-7}, \mathrm{n}=84\right)$. Before being placed on the IVM plate, the oocytes were washed once in a respective medium of each treatment, the base medium of maturation consisting of base TCM-199 bicarbonate plus $10 \%$ fetal bovine serum $(0.11 \mathrm{mg} /$ $\left.\mathrm{mL}^{-1}\right)$, amikacin $\left(83 \mathrm{mg} / \mathrm{mL}^{-1}\right)$, sodium pyruvate $(22$ $\left.\mu \mathrm{g} / \mathrm{mL}^{-1}\right)$, FSH $\left(0.5 \mu \mathrm{g} / \mathrm{mL}^{-1}\right)$, and LH $\left(5 \mu \mathrm{g} / \mathrm{mL}^{-1}\right)$. The oocytes were distributed (10-15 oocytes) in drops of the maturation medium with $100 \mu \mathrm{L}$ and then incubated in an incubator at $38.5^{\circ} \mathrm{C}$ in a humid atmosphere containing 5\% $\mathrm{CO}_{2}$ for 22 to 24 hours. After this period, the oocytes were observed under a stereoscopic microscope to evaluate the expansion of cumulus cells, indicating oocyte maturation.

After maturation, the oocytes were washed in one drop of TALP-FERT medium plus amikacin (83 $\left.\mathrm{mg} / \mathrm{mL}^{-1}\right)$, pyruvate solution $\left(0.11 \mathrm{mg} / \mathrm{mL}^{-1}\right)$, PHE $(2 \mu \mathrm{M}$ penicillamine, $1 \mu \mathrm{M}$ hypotaurine, 1 $\mu \mathrm{M}$ epinephrine), heparin $\left(10 \mu \mathrm{g} / \mathrm{mL}^{-1}\right)$, and bovine serum albumin (BSA) free of essential fatty acids $\left(6 \mathrm{mg} / \mathrm{mL}^{-1}\right)$ in $100 \mu \mathrm{L}$ drops of the same TALPFERT medium and the same distribution of IVM treatments. Fertilization was performed with semen selected from the same Nelore bull for all replicates. The semen reeds were thawed and the spermatozoa submitted to the selection and training process by the mini-Percoll $\AA$ discontinuous gradient centrifugation method adapted from Parrish et al. (1995) and was carried out in 1.5-mL microtubes with $400 \mu \mathrm{L}$ of $45 \%$ Percoll and $400 \mu \mathrm{L}$ of Percoll $90 \%$, thus totaling $800 \mu \mathrm{L}$ of the gradients and rotating at $3500 \mathrm{rpm}$ for 5 minutes. At the end of testing, motility and vigor were evaluated, in addition to the concentration, by counting in the Neubauer chamber with the aid of a light microscope. From this, the semen concentration that was placed per drop was calculated and the inseminating dose used of $1 \times 10^{6}$ spermatozoa/mL, thus considering IVF day as day 0 (D0) of the embryonic development. Fertilization was performed on the IVF plate in drops containing
TALP-FERT medium. The COCs together with the spermatozoa were taken to the incubator by $12: 00$ to 18:00 hours under the same maturation conditions.

After the IVF period, the possible zygotes were stripped and washed in medium with synthetic oviduct fluid (SOF) base supplemented with pyruvate solution $\left(0.11 \mathrm{mg} / \mathrm{mL}^{-1}\right)$, amikacin $(83 \mathrm{mg} /$ $\left.\mathrm{mL}^{-1}\right)$, free fatty acid BSA, low endotoxin $(6 \mathrm{mg}$ / $\mathrm{mL}^{-1}$ ), and fetal bovine serum (2.5\%) and transferred to the IVC culture dish following the same drop/ treatment separation, containing from 10 to 15 zygotes in $100-\mu \mathrm{L}$ drops of medium on SOF basis and incubated at $38.5^{\circ} \mathrm{C}$ in a humid atmosphere containing $5 \% \mathrm{CO}_{2}$ for 7 days. In D3 and D7, production analyzes were performed using the rates of cleavage and blastocysts.

\section{Experiment 2}

The methodology of experiment 2 was based on experiment 1, but the $\mathrm{Kp}$ test was performed in the IVF stage. After selection, the oocytes normally followed the IVM stage without receiving any treatment.

At the end of maturation, the oocytes were transferred to IVF and were randomly assigned to the following treatments: TALP-FERT without Kp (IVF Control, $\mathrm{n}=103$ ) and TALP-FERT with the addition of $10^{-7} \mathrm{M} \mathrm{Kp}\left(\mathrm{Kp} 10^{-7} \mathrm{IVF}, \mathrm{n}=119\right)$. Prior to being placed on the IVF plate, the oocytes were washed once in the respective medium of each treatment and then normally followed the IVF procedure. After this step, the probable zygotes passed to the conventional IVC, maintaining the droplet separation/treatment.

\section{Experiment 3}

In this experiment, the $\mathrm{Kp}$ test was performed during the IVC, and the previous steps were performed in a conventional manner. After fertilization, the oocytes were randomly assigned to 
the following treatments: SOF medium without $\mathrm{Kp}$ (Control IVC, $\mathrm{n}=109$ ) and SOF medium with the addition of $10^{-7} \mathrm{M} \mathrm{Kp}\left(\mathrm{Kp} 10^{-7} \mathrm{IVC}, \mathrm{n}=106\right)$. Prior to being placed on the IVC plate, the oocytes were washed in the respective medium of each treatment and normally followed the IVC procedure.

\section{Embryo production analysis}

Seventy-two hours after fertilization (D3), the cleavage rate was evaluated. At the end of the culture (D7), the blastocyst rate was estimated, in which the embryos were classified by a single observer, as recommended by the International Society of Embryos (STRINGFELLOW; SEIDEL, 1998). These evaluations were all performed using a stereoscopic microscope.

\section{Statistical analysis}

The effect of the treatments was analyzed using SAS 9.3 (2016). The binomial variables were submitted to ProcGLIMMIX, compared by Ismeans, and presented in percentage. Significance was considered when $\mathrm{P}<0.05$.

\section{Results}

In experiment 1 , the mean values of cleavage rates and blastocysts were similar $(\mathrm{P}>0.05)$ between conventional oocyte maturation treatments (IMV Control), maturation with addition of $10^{-7} \mathrm{M} \mathrm{Kp}(\mathrm{Kp}$ $10^{-7}$ IVM), and maturation without hormones LH and $\mathrm{FSH}$ with addition of $10^{-7} \mathrm{M} \mathrm{Kp}$ (No hormones $\left.+\mathrm{Kp} 10^{-7}\right)$. The cleavage rates were $76.47 \%$ (78/102), 80\% (72/90), and 70.24\% (59/84), and the blastocyst rates were $37.25 \%$ (38/102), 33. 33\% (30/90), and 30.95\% (26/84), respectively, for each treatment (Figure 1).

In the second experiment, the mean values found for the cleavage rates were similar $(\mathrm{P}>0.05)$ between treatments. The values of this rate were $76.70 \%$ (79/103) and $86.55 \%$ (103/119) for the IVF control and $\mathrm{Kp} 10^{-7} \mathrm{IVF}$ groups, respectively. On the other hand, the mean blastocyst rate of the $\mathrm{Kp} 10^{-7}$ FIV group was higher $(\mathrm{P}<0.05)$ than that of the IVF control group. Thus, the values of the blastocyst rates were $38.66 \%(46 / 119)$ and 31.07\% (32/103), respectively, for each treatment (Figure 2).

In experiment 3 , the mean values found for the cleavage rates and blastocysts were similar $(\mathrm{P}>0.05)$ between the IVC Control and Kp 10-7 IVC treatments, with cleavage rates being $83.50 \%$ (91/109) and 78. 30\% (83/106), and the blastocyst rates $26.60 \%(29 / 109)$ and $23.60 \%$ (25/106), respectively, for each treatment (Figure 3). 
Figure 1. Mean percentage of cleavage and blastocyst rates of treatments of conventional maturation, maturation with addition of $10^{-7} \mathrm{M} \mathrm{Kp}-10$ and maturation without hormones $\mathrm{LH}$ and FSH, with addition of $10^{-7} \mathrm{M} \mathrm{Kp}-10$, evaluated in D3 and D7, respectively.

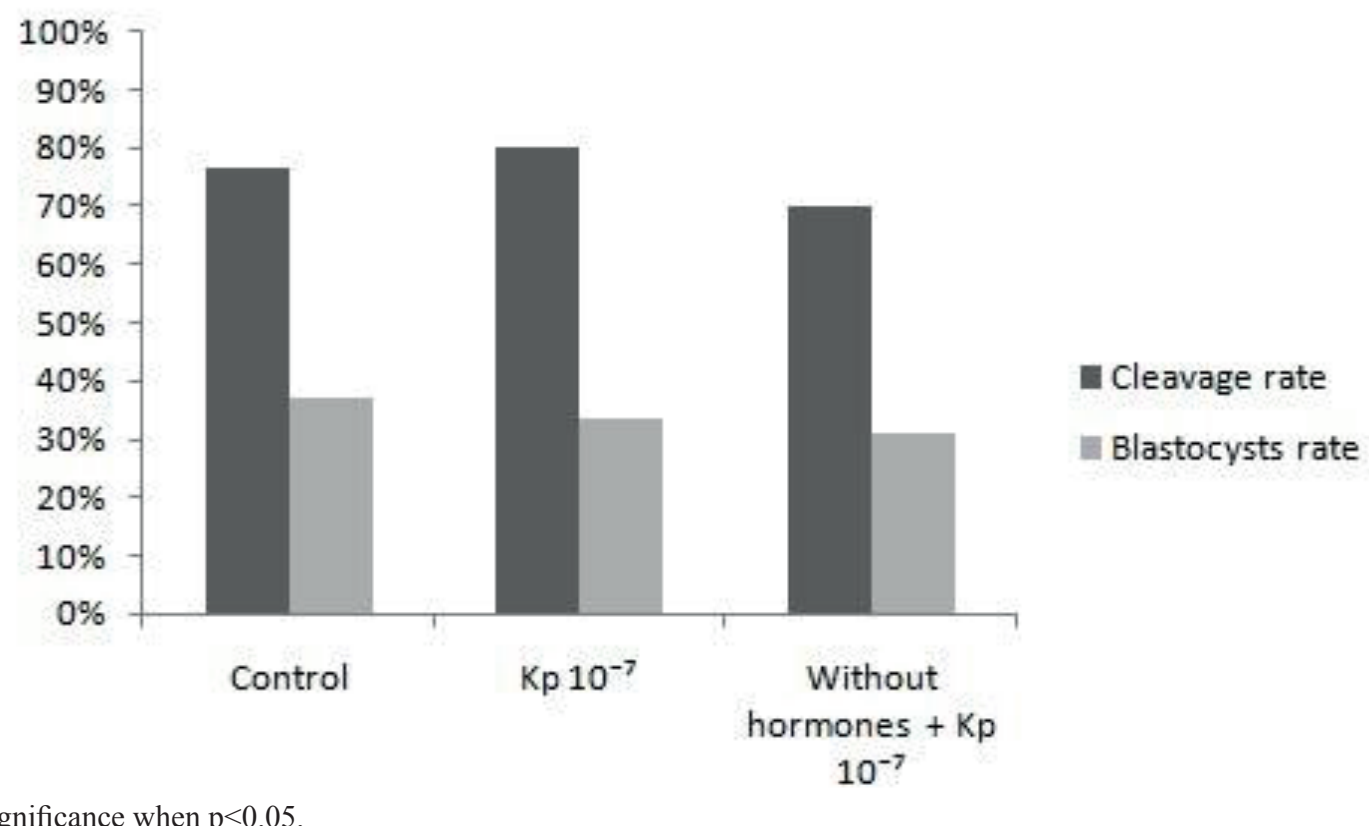

Figure 2. Mean percentage of cleavage and blastocysts rates of treatments IVF Control and $\mathrm{Kp} 10^{-7} \mathrm{IVF}$, evaluated in D3 and D7, respectively.

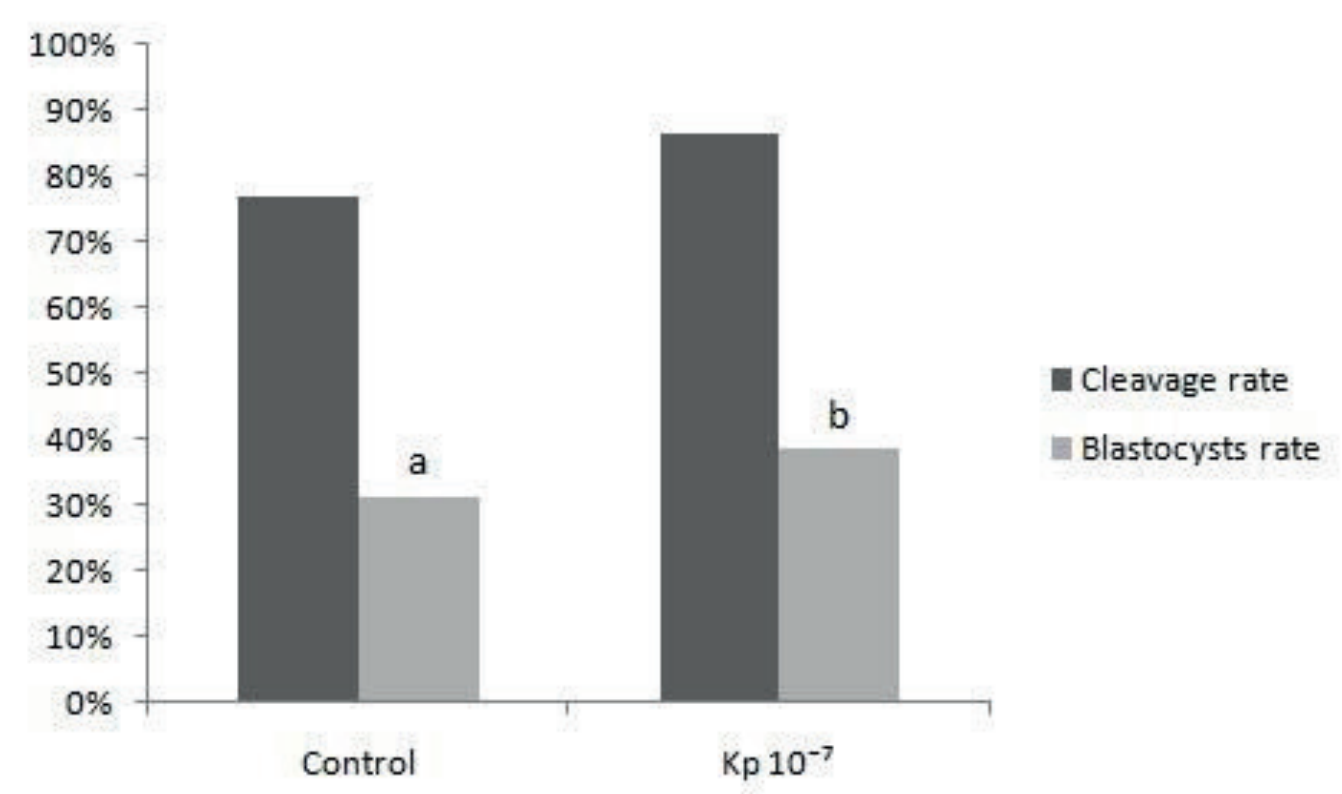

${ }^{\mathrm{a}, \mathrm{b}}$ Different letters means significance $(\mathrm{P}<0.05)$. 
Figure 3. Mean percentage of cleavage and blastocysts rates of treatments IVC Control and $\mathrm{Kp} 10^{-7} \mathrm{IVC}$, evaluated in D3 and D7, respectively.

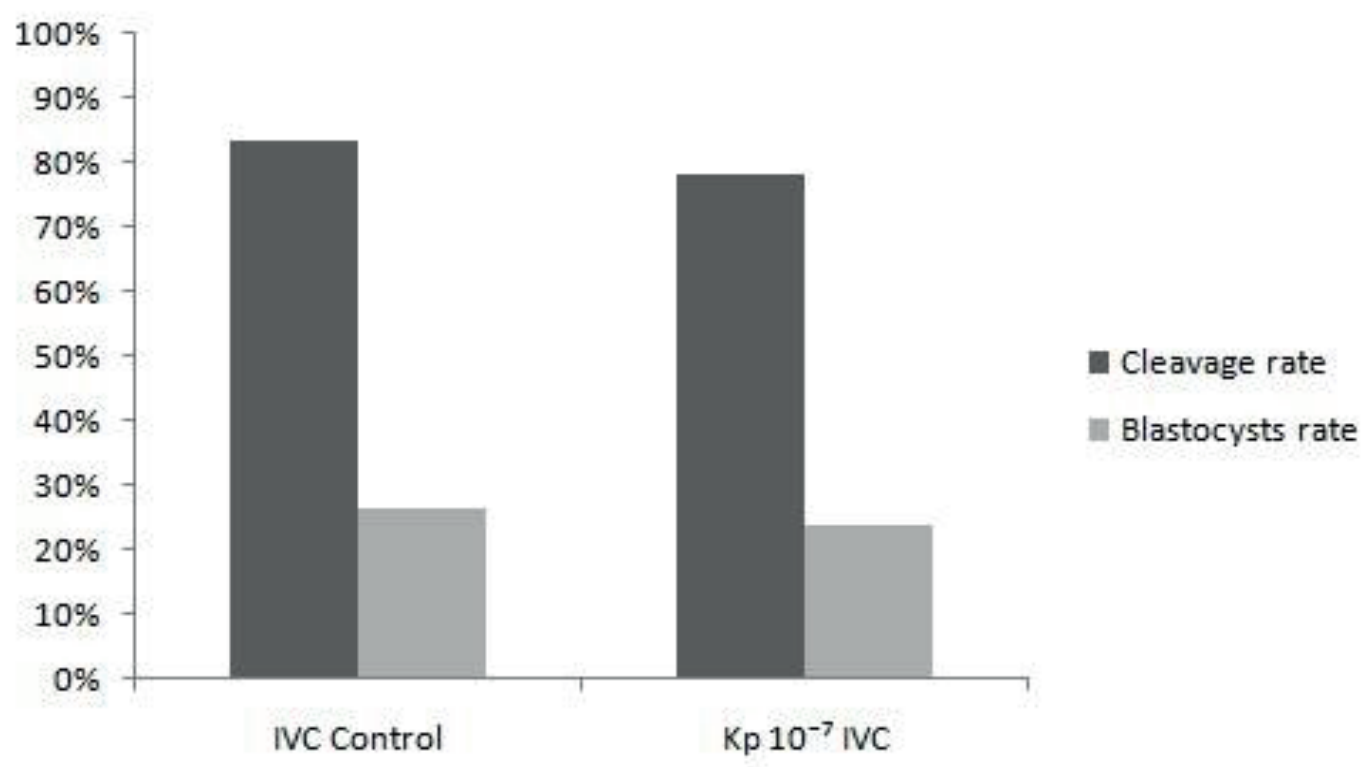

Significance when $\mathrm{P}<0.05$.

\section{Discussion}

The process of in vitro production of bovine embryos is still considered inefficient, presenting a lower quality of blastocysts committed to their competence. Therefore, new alternatives are being tested to be closer to in vivo production, increasing the in vitro production and the quality of the bovine embryos.

In the first experiment, in vitro oocyte maturation supplemented with $\mathrm{Kp}$ did not result in higher cleavage rates and blastocysts compared to the conventional medium. The treatment of maturation with the addition of $\mathrm{Kp}$ did not present a better result, probably due to the high concentration of gonadotrophins in the medium, resulting in the saturation of the LH receptors in cumulus cells (MCFARLAND et al., 1989) and FSH in oocytes (MÉDURI et al., 2002). However, the presence of $\mathrm{Kp}$ in the hormone-free maturation medium maintained similar control rates. This demonstrates that the use of this neuropeptide in the base medium of IVM can replace the use of the hormones LH and FSH, since they presented the same production. In this way, the cost of the process and the chance of contamination can be diminished, since the neuropeptide is of synthetic manufacture with a high degree of purity. In addition, $\mathrm{Kp}$ has been shown to play an important role in the regulation of mammalian fertility due to its direct action on hypothalamic neurons, stimulating the secretion of $\mathrm{GnRH}$ in vivo and consequently of LH and FSH gonadotrophins (DHILLO et al., 2005; DIAS et al., 2015; HASHIZUME et al., 2010). Saadeldin et al. (2012) reported that in vitro Kp indirectly affects oocyte maturation due to increased LH production by activation of $\mathrm{GnRH} \alpha$ expressed in oocytes and cumulus cells during IVM.

In the second experiment, $\mathrm{Kp}$ resulted in improvements in blastocyst production rates when added to the IVF stage. This result can be explained by the probable presence of Kiss1r and Kiss1 in bovine spermatozoa, as has been reported in other species such as mice (HSU et al., 2014) and humans (PINTO et al., 2012), allowing Kp to modulate fertilization, in order to improve the fertilization 
capacity of the spermatozoon. Some of the effects of this neuropeptide on spermatozoa result from their ability to locally modulate GnRH secretion, $\mathrm{GnRH}$ and its receptor are present in several additional hypothalamic tissues, including oviduct, ovarian granulosa cells, and spermatozoa (IZUMI et al., 1985; LEE et al., 2000; MORALES, 1998). This hormone increases spermatozoa's ability to bind to the zona pellucida, but is not capable of inducing the acrosome reaction or modifying the motile pattern in human spermatozoa (MORALES, 1998). In addition, the neuropeptide also promotes an increase in the concentration of intracellular calcium in the spermatozoa, inducing significant changes in sperm motility (PINTO et al., 2012; HSU et al., 2014) and is also important in acupuncture training and reaction (COSTELLO et al., 2009).

In the third experiment, the supplementation of the culture medium with $\mathrm{Kp}$ had no effect on the rates of cleavage and blastocysts. In addition, $\mathrm{Kp}$ has a metastatic suppressor molecule, controlling proliferation and cell migration (OHTAKI et al., 2001), and it can also control embryonic cell divisions, since this activity can be confused with disordered cell multiplication. In this case, this neuropeptide may act by inhibiting the growth of disseminated cancer cells at a secondary site, suppressing metastasis without affecting primary tumor growth (GOLDBERG et al., 1999; KAUFFMAN et al., 2003; YOSHIDA et al., 1999). Research studies such as those by Wang et al. (2005) and Ji et al. (2013) have shown this effect to be a metastatic suppressor molecule by observing that reduced levels of KISS1 and Kp expression were correlated with invasion and metastasis of pancreatic cancer. In addition, Kp plays a role in the endocrine-paracrine regulation of the trophoblast invasion (TERAO et al., 2004) of the uterine extracellular matrix, repressing this critical and essential process for the embryonic development that resembles a tumor cell invasion, but controlled (HIDEN et al., 2007; ROSEWEIR et al., 2012).
According to Saaldeldin et al. (2012), embryos cultured in media supplemented with Kp presented their affected trophoblastic viability, presenting 3 to 5 times more degeneration than those cultured without this neuropeptide, due to the impediment of the trophoblast growth, leading to a degeneration of the trofectoderma.

\section{Conclusion}

The maturation medium without FSH and $\mathrm{LH}$, supplemented with $\mathrm{Kp}$, was able to perform a maturation similar to mature oocytes with the use of these standard hormones, thus demonstrating that $\mathrm{Kp}$ replacement may be an alternative for IVM. In addition, it was also evidenced that this neuropeptide proved to be a good alternative for use in IVF as it improved the production of embryos in vitro.

Thus, it can be concluded that $\mathrm{Kp}$ presents a regulatory action on bovine reproduction, and can be an excellent tool to maximize the indices of the in vitro production of embryos, thus requiring more in-depth knowledge about this neuropeptide.

\section{Acknowledgement}

The authors are thankful to National Council for Scientific and Technological Development (CNPq) for financial support for this project.

\section{References}

CASTELLANO, J. M.; GAYTAN, M.; ROA, J.; VIGO, E.; NAVARTO, V. M.; BELLIDO, C.; DIEGUEZ, C.; AGUILAR, E.; SÁNCHEZ-CRIADO, J. E.; PELLICER, A.; PINILLA, L.; GAYTAN, F.; TENA-SEMPERE, M. Expression of KiSS-1 in rat ovary: putative local regulator of ovulation? Endocrinology, Whashington, v. 147, n. 10, p. 4852-4862, 2006.

COSTELLO, S.; MICHELANGELI, F.; NASH, K.; LEFIEVRE, L.; MORRIS, J.; MACHADO- OLIVEIRA, G.; BARRATT, C.; KIRKMAN-BROWN， J.; PUBLICOVER, S. Ca2+-stores in sperm: their identities and functions. Reproduction, Teddington, v. 138, n. 3, p. 425-437, 2009. 
LIMA, A. C. B. de; STERZA, F. M. A produção in vitro de embriões de genética especializada da raça girolando. Anais do Semex, Dourados, n. 8, 2015.

DHILlO, W. S.; CHAUDHRI, O. B.; PATTERSON, M.; THOMPSON, E. L.; MURPHY, K. G.; BADMAN, M. K.; MCGOWAN, B. M.; AMBER, V.; PATEL, S.; GHATEI, M. A.; BLOOM, S. R. Kisspeptin-54 stimulates the hypothalamic-pituitary gonadal axis in human males. The Journal of Clinical Endocrinology and Metabolism, Oxford, v. 90, n. 12, p. 6609-6615, 2005.

DIAS, J. C. O.; VELOSO, C. M.; OLIVEIRA DONZELE, R. F. M. de; CARVALHO, G. R. de. O neuropeptídeo kisspeptina e a reprodução animal: uma revisão. MultiScience Journal, Urutaí, v. 1, n. 2, p. 96-110, 2015.

EZZAT, A, A.; SAITO, H.; SAWADA, T.; YAEGASHI, T.; GOTO, Y.; NAKAJIMA, Y.; JIN, J.; YAMASHITA, T. K.; SAWAI K.; HASHIZUME, T. The role of sexual steroid hormones in the direct stimulation by Kisspeptin-10 of the secretion of luteinizing hormone, follicle-stimulating hormone and prolactin from bovine anterior pituitary cells. Animal Reproduction Science, Amsterdam, v. 121, n. 3, p. 267-272, 2010.

GAYTAN, F.; GAYTAN, M.; CASTELLANO, J. M.; ROMERO, M.; ROA, J.; APARICIO, B.; GARRIDO, N.; SÁNCHEZ-CRIADO, J. E.; MILLAR, R. P.; PELLICER, A.; FRASER, H. M.; TENA-SEMPERE, M. KiSS-1 in the mammalian ovary: distribution of kisspeptin in human and marmoset and alterations in KiSS-1 mRNA levels in a rat model of ovulatory dysfunction. American Journal of Physiology - Endocrinology and Metabolism, Bethesda, v. 296, n. 3, p. E520-E531, 2009.

GOLDBERG, S. F.; HARMS, J. F.; QUON, K.; WELCH, D. R. Metastasis-suppressed C8161 melanoma cells arrest in lung but fail to proliferate. Clinical and Experimental Metastasis, Netherlands, v. 17, n. 7, p. 601-607, 1999.

GUTIÉRREZ-PASCUAL, E.; MARTÍNWZ-FUENTES, A. J.; PINILLA, L.; TENA-SEMPERE, M.; MALAGÓN, M. M.; CASTÑO, J. P. Direct pituitary effects of kisspeptin: activation of gonadotrophs and somatotrophs and stimulation of luteinising hormone and growth hormone secretion. Journal of Neuroendocrinology, Hoboken, v. 19, n. 7, p. 521-530, 2007.

HASHIZUME, T.; SAITO, H.; SAWADA, T.; YAEGASHI, T.; AHMED-EZZAT, A.; SAWAI, K.; YAMASHITA, T. Characteristics of stimulation of gonadotropin secretion by kisspeptin-10 in female goats. Animal Reproduction Science, Amsterdam, v. 118, n. 1, p. 37-41, 2010 .

HIDEN, U.; BILBAN, M.; KNÖFLER, M.; DESOYE, G. Kisspeptins and the placenta: regulation of trophoblast invasion. Reviews in Endocrine and Metabolic Disorders, New York, v. 8, n. 1, p. 31-39, 2007.
HSU, M. C.; WANG, J. Y.; LEE, Y. J.; JONG, D. S.; TSUI, K. H.; CHIU, C. H. Kisspeptin modulates fertilization capacity of mouse spermatozoa. Reproduction, Teddington, v. 147, n. 6, p. 835-845, 2014.

IZUMI, S. I.; MAKINO, T.; IIZUKA, R. Immunoreactive luteinizing hormone-releasing hormone in the seminal plasma and human semen parameters. Fertility and Sterility, New York, v. 43, n. 4, p. 617-620, 1985.

JI, K.; YE, L.; MASON, M. D.; JIANG, W. G. The Kiss-1/Kiss-1R complex as a negative regulator of cell motility and cancer metastasis (Review). International Journal of Molecular Medicine, Atenas, v. 32, n. 4, p. 747-754, 2013.

KAUFFMAN, E. C.; ROBINSON, V. L.; STADLER, W. M.; SOKOLOFF, M. H.; RINKER-SCHAEFFER, C. W. Metastasis suppression: the evolving role of metastasis suppressor genes for regulating cancer cell growth at the secondary site. The Journal of Urology, Linthicum, v. 169, n. 3, p. 1122-1133, 2003.

LEE, C. Y. G.; HO, J.; CHOW, S. N.; YASOJIMA, K.; SCHWAB, C.; MCGEER, P. L. Immunoidentification of gonadotropin releasing hormone receptor in human sperm, pituitary and cancer cells. American Journal of Reproductive Immunology, Medford, v. 44, n. 3, p. 170$177,2000$.

LEE, J. H.; MIELE, M. E.; HICKS, D. J.; PHILLIPS, K. K.; TRENT, J. M.; WEISSMAN, B. E.; WELCH, D. R. KiSS-1, a novel human malignant melanoma metastasissuppressor gene. Journal of the National Cancer Institute, Oxford, v. 88, n. 23, p. 1731-1737, 1996.

LEIBFRIED, L.; FIRST, N. L. Characterization of bovine follicular oocytes and their ability to mature in vitro. Journal of Animal Science, Champaign, v. 48, n. 1, p. 76-86, 1979.

LONERGAN, P.; FAIR, T. In vitro-produced bovine embryos - dealing with the warts. Theriogenology, Stoneham, v. 69, n. 1, p. 17-22, 2008.

MACEDO, G. G.; MAIO, J. R. G.; MONTEIRO, B. M.; BATISTA, E. S.; SALA, R. V.; VIEIRA, L. M.; SOARES, J. G.; SÁ FILHO, M. F.; SANTOS, G. M.; MENDANHA, M. F.; NOGUEIRA, G. P.; BARUSELLI, P. S. Kisspeptin stimulates LH release, is enhanced by estradiol and induces ovulation in bovine females. In: ANNUAL MEETING OF THE BRAZILIAN EMBRYO TECHNOLOGY SOCIETY - SBTE, 27., 2013, Praia do Forte. Proceedings... Uberlândia: CBRA, 2013. v. 1, p. 411-411.

MAPLETOFT, R. J. History and perspectives on bovine embryo transfer. Animal Reproduction, Belo Horizonte, v. 10, n. 3 , p. $168-173,2013$. 
MCFARLAND, K. C.; SPRENGEL, R.; PHILLIPS, H. S.; KOHLER, M.; ROSEMBLIT, N.; NIKOLICS, K.; SEGALOFF, D. L.; SEEBURG, P. H. LutropinChoriogonadotrophin receptor: an unusual member of the G protein-couple receptor family. Science, Washington, v. 245, n. 4917, p. 494-499, 1989.

MÉDURI, G.; CHARNAUX, N.; DRIANCOURT, M. A.; COMBETTES, L.; GRANET, P.; VANNIER, B.; LOOSFELT, H.; MIGROM, E. Follicle-stimulating hormone receptors in oocytes? The Journal of Clinical Endocrinology \& Metabolism, Oxford, v. 87, n. 5, p. 2266-2276, 2002.

MORALES, P. Gonadotropin-releasing hormone increases ability of the spermatozoa to bind to the human zona pellucida. Biology of Reproduction, Madison, v. 59, n. 2, p. 426-430, 1998.

OHTAKI, T.; SHINTANI, Y.; HONDA, S.; MATSUMOTO, H.; HORI, A.; KANEHASHI, K.; TERAO, Y.; KUMANO, S.; TAKATSU, Y.; MASUDA, Y.; ISHIBASHI, Y.; WATANABE, T.; ASADA, M.; YAMADA, T.; SUENAGA, M.; KITADA, C.; USUKI, S.; KUROKAWA, T.; ONDA, H.; NISHIMURA, O.; FUJINO, M. Metastasis suppressor gene KiSS-1 encodes peptide ligand of a G-protein-coupled receptor. Nature, Londres, v. 411, n. 6837, p. 613-617, 2001.

OKAMURA, H.; YAMAMURA, T.; WAKABAYASHI, Y. Kisspeptin as a master player in the central control of reproduction in mammals: an overview of kisspeptina research in domestic animals. Animal Science Journal, Medford, v. 84, n. 5, p. 369-381, 2013.

PARRISH, J. J.; KROGENAES, A.; SUSKO-PARRISH, J. L. Effect of bovine sperm separation by either swimup or Percoll method on success of in vitro fertilization and early embryonic development. Theriogenology, Stoneham, v. 44, n. 6, p. 859-869, 1995.

PINILLA, L.; AGUILAR, E.; DIEGUEZ, C.; MILLAR, R. P.; TENA-SEMPERE, M. Kisspeptins and reproduction: physiological roles and regulatory mechanisms. Physiological Reviews, Bethesda, v. 92, n. 3, p. 1235-1316, 2012.

PINTO, F. M.; CEJUDO-ROMAN, A.; RAVINA, C. G.; FERNANDEZ-SANCHEZ, M.; MARTINLOZANO, D.; ILLANES, M.; TENA-SEMPERE, M.; CANDENAS, M. L. Characterization of the kisspeptin system in human spermatozoa. International Journal of Andrology, Oxford, v. 35, n. 1, p. 63-73, 2012.

REDMOND, J. S.; MACEDO, G. G.; VELEZ, I. C.; CARATY, A.; WILLIAMS, G. L.; AMSTALDEN,
M. Kisspeptin activates the hypothalamicadenohypophyseal-gonadal axis in prepubertal ewe lambs. Reproduction, Teddington, v. 141, n. 4, p. 541548, 2011.

ROSEWEIR, A. K.; KATZ, A. A.; MILlAR, R. P. Kisspeptin-10 inhibits cell migration in vitro via a receptor-GSK3 beta-FAK feedback loop in HTR8SVneo cells. Placenta, Philadelphia, v. 33, n. 5, p. 408-415, 2012.

SAADELDIN, I. M.; KOO, O. J.; KANG, J. T.; KWON, D. K.; PARK, S. J.; KIM, S.; PARK, S. J.; KIM, S. J.; MOON, J. H.; HYUN, J. O.; JANG, G.; LEE, B. C. Paradoxical effects of kisspeptin: it enhances oocyte in vitro maturation but has an adverse impact on hatched blastocysts during in vitro culture. Reproduction, Fertility and Development, East Melbourne, v. 24, n. 5, p. 656-668, 2012.

STATISTICAL ANALYSIS SYSTEM INSTITUTE SAS. The SAS System, release 9.3. SAS Institute Inc., Cary: NC, 2016.

STRINGFELLOW, D. A.; SEIDEL, S. M. Manual da sociedade internacional de transferência de embriões. 3. ed. Illinois: IETS, 1998. 180 p.

TERAO, Y.; KUMANO, S.; TAKATSU, Y.; HATTORI, M.; NISHIMURA, A.; OHTAKI, T.; SHINTANI, Y. Expression of KiSS-1, a metastasis suppressor gene, in trophoblast giant cells of the rat placenta. Biochimica et BiophysicaActa (BBA)-Gene Structure and Expression, Netherlands, v. 1678, n. 2, p. 102-110, 2004.

WANG, C. H.; QIAO, C.; MA, S. R.; ZHOU, W. P.; DAI, $\mathrm{X}$. W. Expression of KiSS-1 in human pancreatic cancer and relationship with their invasion and metastasis. China Journal of Modern Medicine, Haidian District Beijing, v. 15, p. 1620-1623, 2005.

YOSHIDA, B. A.; DUBAUSKAS, Z.; CHEKMAREVA, M. A.; CHRISTIANO, T. R.; STADLER, W. M.; RINKER-SCHAEFFER, C. W. Mitogenactivated protein kinase kinase 4/stress-activated protein/Erk kinase 1 (MKK4/SEK1), a prostate cancer metastasis suppressor gene encoded by human chromosome 17. Cancer Research, Philadelphia, v. 59, n. 21, p. 5483-5487, 1999.

ZHAO, S.; ZHU, E.; YANG, C.; BENTLEY, G. E.; TSUTSUI, K.; KRIEGSFELD, L. J. RF amide-related peptide and messenger ribonucleic acid expression in mammalian testis: association with the spermatogenic cycle. Endocrinology, Washington, v. 151, n. 2, p. 617$627,2010$. 